\title{
Inflammatory markers, endothelial function and cardiovascular risk
}

\author{
Marcadores inflamatórios, função endotelial e riscos cardiovasculares
}

Bruno Costa Teixeira', André Luiz Lopes', Rodrigo Cauduro Oliveira Macedo', Cleiton Silva Correa², Thiago Rozales Ramis ${ }^{3}$, Jerri Luiz Ribeiro ${ }^{3}$, Alvaro Reischak-Oliveira ${ }^{1}$

\begin{abstract}
The need to study cardiovascular diseases (CVD) has become more and more relevant as their prevalence has increased over the years. An intact endothelial wall is essential to vascular health. Certain factors are responsible for maintaining this tissue intact, including nitric oxide (NO), which provokes dilation of blood vessels in response to shear stress. Expression of the endothelial nitric oxide synthase (eNOS) enzyme, which produces nitric oxide in response to increases in blood flow, is of fundamental importance to maintenance of the vascular system. When this enzyme is inhibited, nitric oxide production is reduced, causing endothelial dysfunction. Since C-reactive protein inhibits production of nitric oxide by the eNOS enzyme, it is one of the causes of endothelial dysfunction and cardiovascular events. The objective of the present study was to review scientific articles in the literature related to the subject 'inflammatory markers and endothelial function'. A wide-ranging review of the current literature was conducted, using systematic analysis of bibliographic references indexed in PubMed, Scielo, Medline and LILACS database, for the years 1992 to 2013. The studies reviewed show that increases in inflammation causes reductions in NO and increases in cardiovascular events. Increased inflammation is associated with higher incidence of cardiovascular diseases.
\end{abstract}

Keywords: inflammation; nitric oxide; endothelium.

\section{Resumo}

A necessidade de estudo das Doenças Cardiovasculares (DCV) vem à tona pelo aumento da sua prevalência ao longo dos anos. Uma parede endotelial íntegra é essencial para a saúde vascular. Alguns fatores são responsáveis pela integridade deste tecido, como o óxido nítrico (NO), que provoca a dilatação do vaso sanguíneo em resposta ao estresse de cisalhamento. A expressão da enzima óxido nítrico sintase endotelial (eNOS), que produz óxido nítrico em resposta ao incremento do fluxo sanguíneo, é fundamental para a manutenção do sistema vascular. Quando há inibição desta enzima, ocorre diminuição da produção de óxido nítrico, causando disfunção endotelial. A PCR inibe a produção de óxido nítrico pela enzima eNOS, sendo então uma causadora de disfunção endotelial e eventos cardiovasculares. O presente artigo tem como objetivo revisar artigos científicos na literatura relacionados ao tema 'marcadores inflamatórios e função endotelial'. Foi realizada uma ampla revisão de literatura atual, utilizando-se análise sistemática das referências bibliográficas nas bases de dados PubMed, Scielo, Medline e Lilacs, no período de 1992 a 2013. Os estudos revisados mostram que o aumento da inflamação causa uma diminuição de NO e aumento de eventos cardiovasculares. O aumento da inflamação está associado ao aumento da incidência de doenças cardiovasculares.

Palavras-chave: inflamação; óxido nítrico; endotélio.

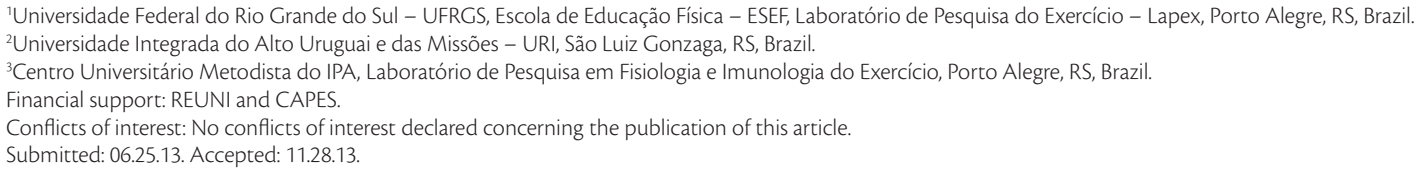




\section{INTRODUCTION}

There are currently more than 83.6 million Americans with cardiovascular diseases (CVD) and it is estimated that they incur costs of 300 billion dollars of public money per year. ${ }^{1}$ In Brazil, CVD are among the leading causes of death. In 2007, mortality attributable to these diseases was around 250 per 100 thousand people. This is a higher prevalence than is seen in the United States, where the figure is 179 per 100 thousand. $^{2}$ The layer that lines the internal surface of blood vessels is called endothelium, forming an extensive cellular tissue covering the entire vascular network, from the major veins and arteries to minor vessels, arterioles and capillaries. Endothelium plays a role in vascular homeostasis and has many endocrine, autocrine and paracrine functions, ${ }^{3}$ which is why it is responsible for synthesizing vasoconstrictor and vasodilator substances. ${ }^{4}$

Intact endothelium plays a protective role in blood vessels that is triggered by physiological stimuli such as shear stress exerted by blood flow against endothelial cells, resulting in production of nitric oxide (NO), the function of which is to maintain the blood vessel in a constant state of vasodilation. ${ }^{5}$ In contrast, endothelin-1 (ET-1) has the opposite effect to NO, with a vasoconstrictor action. ${ }^{6}$

Endothelial dysfunction is an imbalance between vasodilation and vasoconstriction, and is related to atherosclerosis and cardiovascular events. It is also defined as an imbalance between mediators that regulate vascular tone and hemostasis. ${ }^{\text {? }}$

Certain risk factors such as dyslipidemia and arterial hypertension cause vascular damage and progressive loss of endothelial protective functions, thereby increasing oxidative stress and inflammation. Inflammation appears to be a key point in all of the stages of the atherosclerosis process, from emergence of the lesion to occurrence of a coronary event. ${ }^{8}$

The chronic vascular inflammatory process has a fundamental relationship with endothelial capacity to produce proinflammatory cytokines, factors and adhesion molecules. ${ }^{7}$ Certain cytokines and factors, such as Interleukin-6 (IL-6) and tumor necrosis factor alpha (TNF- $\alpha$ ) respectively, are released by the endothelium, stimulating adhesion molecules and increasing vascular risk. ${ }^{9}$ Interleukin- 6 is an important cytokine involved in many different immunological processes and takes part in metabolic regulation of C-reactive protein (CRP). During an inflammatory reaction, IL-6 and CRP can have undesirable effects on a number of organs. ${ }^{10}$ Increases in serum IL-6 and CRP levels can cause down regulation of NO production, by inhibiting endothelial nitric oxide synthase (eNOS), facilitating thrombi formation and, consequently, increasing the risk of cardiovascular events. ${ }^{11,12}$

In view of the above, the objective of this article is to present a review of scientific articles in the literature related to the subject 'inflammatory markers and endothelial function'.

In preparation for this article, the authors conducted a wide-ranging review of the current literature, using systematic analysis of bibliographic references indexed in PubMed, Scielo, Medline and LILACS database, for the years 1992 to 2013, found using the following keywords: inflammation, interleukin-6, C-reactive protein, nitric oxide and endothelial function.

\section{ENDOTHELIAL FUNCTION}

For some time now, it has been recognized that endothelium is not merely a physical barrier between blood and the vascular wall, but a strategically located organ with a large number of endocrine, autocrine and paracrine functions. ${ }^{3}$

Endothelium is highly specialized tissue that regulates vascular homeostasis. Its basic functions are to regulate vascular tone, leukocyte adhesion, smooth muscle cell growth and platelet aggregation. Physiologically, endothelium plays a protective role in blood vessels. The protective action is triggered by physiological stimuli such as the shear stress exerted by blood flow against endothelial cells, which results in basal production of NO, maintaining the blood vessel in a constant state of vasodilation. ${ }^{5,10}$

Nitric oxide plays an active part in many of the protective functions performed by the intact endothelium and, in conjunction with Prostacyclin-2 (PGI-2), it exerts a potent antiatherogenic effect, preventing platelet adhesion and aggregation. ${ }^{13}$

Palmer et al. conducted an in vivo study that clearly demonstrated how NO and ET-1, which have opposing effects, regulate vascular tone and arterial blood pressure. Loss of functional integrity or endothelial dysfunction is also linked to reduced NO expression and increases ET-1. ${ }^{14}$

Endothelial dysfunction is an imbalance between endothelial production of mediators that regulate vascular tone, platelet aggregation, coagulation and fibrinolysis, of which vascular tone has received the greatest research focus. Endothelial dysfunction is also often defined as a deterioration in endotheliumdependent relaxation, caused, by reduced NO bioavailability, among other factors. ${ }^{14}$ Certain diseases such as arterial hypertension, diabetes mellitus, 
heart failure and hypercholesterolemia can damage the endothelium, causing endothelial dysfunction, which is very often related to atherosclerosis and cardiovascular events. ${ }^{7}$

\section{ENDOTHELIAL \\ FUNCTION \\ INFLAMMATION}

AND

Inflammation appears to be one of the most important points in the atherosclerosis process, from emergence of the lesion to occurrence of a coronary event. ${ }^{8}$ Inflammation causes increased production of reactive oxygen species, which ultimately results in a process of endothelial dysfunction. ${ }^{15}$

The most important characteristic of endothelial dysfunction is its detrimental effect on endotheliumdependent vasodilation. This is the result of an imbalance between NO synthesis and production of reactive oxygen species, which, in turn, can be diagnosed using ultrasonographic assessment of vascular reactivity. ${ }^{16}$ In the intact vascular wall, the potent vasodilator NO is synthesized by eNOS. ${ }^{17}$ In blood vessels subjected to the atherosclerotic process, two NOS isoforms contribute to NO production: neuronal NOS (nNOS) and inducible NOS (iNOS), the second of which is triggered by proinflammatory cytokines. ${ }^{18}$ Under certain conditions, when the cofactor tetrahydrobiopterin is lacking, the amino acid L-arginine (enzyme substrate) can produce greater quantities of superoxide than NO, by means of NOS, in a condition known as NOS decoupling. Together, nitric oxide and superoxide can form peroxynitrite, which can cause oxidation of tetrahydrobiopterin, a critical cofactor for eNOS, completing a vicious circle of reactive oxygen species production. ${ }^{19,20}$

Some studies have shown inflammatory markers such as IL-6 and CRP acting directly in NO down regulation, thereby increasing the endothelial dysfunction process by reducing $\mathrm{NO}$ concentration and increasing ET-1. ${ }^{15,21,22}$

A growing number of studies in human beings have related increased inflammation to reduced availability of $\mathrm{NO}$, providing evidence that chronic inflammation or infection can cause endothelial dysfunction. ${ }^{23-26}$ For example, researchers have investigated differences in endothelial function after acute administration of proinflammatory factors to young individuals. Alternatively, some researchers are conducting observational studies that demonstrate correlations between increases in circulatory proinflammatory marker levels and reduced endothelial function in a range of different populations and types of pathology (Table 1)..$^{27-29}$

Low-level chronic inflammations can be caused by many different factors, such as chronic injuries, diabetes and obesity, among other diseases. ${ }^{30}$ The increase in inflammation provokes increased synthesis of cells, cytokines and proinflammatory proteins, such as neutrophils, monocytes, IL-6, TNF- $\alpha$ and CRP, among others. ${ }^{31}$ The increase in neutrophils and macrophages in response to

Table 1. Studies of inflammatory markers and endothelial function chosen for review.

\begin{tabular}{|c|c|c|c|c|}
\hline Authors & Population & Inflammatory marker & $\begin{array}{l}\text { Measure of endo- } \\
\text { thelial function }\end{array}$ & Results \\
\hline $\begin{array}{l}\text { Fichtlscherer et al. } \\
(2000)^{23}\end{array}$ & 60 men with CAD & CRP, TNF- $\alpha$, sICAM-1 & FBF acetylcholine & $\begin{array}{l}\text { Inverse correlation between } \\
\text { CRP and endothelial function }\end{array}$ \\
\hline Sinisalo et al. $(2000)^{24}$ & 31 men with CAD & $\begin{array}{l}\text { CRP, LDL-ox, CD4 and } \\
\text { CD8 counts }\end{array}$ & FBF acetylcholine & $\begin{array}{l}\text { Inverse correlation between } \\
\text { endothelial function, CRP, } \\
\text { LDL-ox and CD8 count }\end{array}$ \\
\hline Tan et al. $(2002)^{25}$ & $\begin{array}{l}80 \text { patients with type II diabetes } \\
\text { and hypercholesterolemia }\end{array}$ & CRP & $\begin{array}{l}\text { FMD of brachial } \\
\text { artery }\end{array}$ & $\begin{array}{l}\text { Inverse correlation between } \\
\text { FMD and CRP }\end{array}$ \\
\hline Brevetti et al. $(2003)^{26}$ & 88 patients with $\mathrm{PAD}$ & CRP and fibrinogen & $\begin{array}{l}\text { FMD of brachial } \\
\text { artery }\end{array}$ & $\begin{array}{l}\text { Inverse correlation between } \\
\text { CRP, Fibrinogen and FMD }\end{array}$ \\
\hline $\begin{array}{l}\text { De Haro Miralles et al. } \\
(2009)^{27}\end{array}$ & $\begin{array}{l}82 \text { patients with PAD and } 41 \\
\text { healthy subjects }\end{array}$ & CRP and nitrites & $\begin{array}{l}\text { FMD of brachial } \\
\text { artery }\end{array}$ & $\begin{array}{l}\text { Increased CRP in patients } \\
\text { with PAD }\end{array}$ \\
\hline Rizzo et al. (2009) ${ }^{28}$ & $\begin{array}{l}127 \text { hypertense women } \\
\text { followed-up over } 5 \text { years }\end{array}$ & CRP and fibrinogen & $\begin{array}{l}\text { Doppler ultra- } \\
\text { sound of the } \\
\text { carotid }\end{array}$ & $\begin{array}{l}\text { positive correlation between } \\
\text { CRP and increased athero- } \\
\text { sclerosis in the carotid }\end{array}$ \\
\hline $\begin{array}{l}\text { Antoniades et al. } \\
(2011)^{29}\end{array}$ & $\begin{array}{l}351 \text { patients with } C A D \\
87 \text { controls }\end{array}$ & IL-6 & $\begin{array}{l}\text { FMD of brachial } \\
\text { artery }\end{array}$ & $\begin{array}{l}\text { Inverse correlation between } \\
\text { IL-6 and FMD in patients } \\
\text { with CAD }\end{array}$ \\
\hline $\begin{array}{l}\text { Leinonen, Hurt-Camejo } \\
\text { et al. }(2003)^{30}\end{array}$ & 166 healthy subjects & sICAM-1 and CRP & $\begin{array}{l}\text { FMD of brachial } \\
\text { artery }\end{array}$ & $\begin{array}{l}\text { Inverse correlation between } \\
\text { sICAM-1, CRP and FMD }\end{array}$ \\
\hline
\end{tabular}

CRP - C-reactive protein; TNF- $\alpha$ - Tumor necrosis factor alpha; sICAM-1 - Soluble intracellular adhesion molecule-1; LDL-ox - oxidized low density lipoprotein; IL-6 - Interleukin-6; CAD - Coronary artery disease; PAD - Peripheral arterial disease; FBF - Forearm blood flow; FMD - Flow-mediated dilation. 
inflammation provokes greater synthesis of IL-6, which increases production of CRP in the liver. In turn, CRP attenuates eNOS activity, thereby reducing NO availability (a vasodilator), and increasing concentrations of ET-1 (a vasoconstrictor); which attenuates the process of endothelium-dependent vasodilation. The reduction in vasodilation causes an increase in shear stress and, consequently, greater damage to the blood vessel, creating favorable conditions for the atherosclerotic process and thrombi formation. Additionally, the blood vessel that is undergoing the atherosclerotic process also releases the same proinflammatory substances, further increasing the inflammatory process and vascular damage $^{30-32}$ (Figure 1).

\section{IL-6 AND ENDOTHELIUM}

Interleukin 6 is a cytokine that performs functions in both innate and adaptive immunoresponses. It is synthesized by monocytes, endothelial cells, fibroblasts and other types of cells in response to microorganisms, but can also be stimulated by other cytokines, primarily interleukin-1 (IL-1) and TNF- $\alpha .^{3.3}$

Since IL-6 is involved in a series of immunological activities, in particular synthesis of acute phase substances in the liver, it is an important inflammatory marker, because it is involved in metabolic regulation of CRP. ${ }^{10}$ Both IL-6 and its receptor (gp130), are widely expressed during an inflammatory reaction, leading to undesirable effects on several organs. ${ }^{10}$ Normally IL-6 is expressed in low concentrations, except during infections, traumas or in the presence of other stressing factors. Estrogen and testosterone are among the many factors that regulate expression of the IL-6 gene. After menopause or andropause, serum IL-6 levels are elevated even in the absence of infection, trauma or stress. ${ }^{34}$

Hyperglycemia, which is characteristic of glucose intolerance, has a relationship with immediate synthesis of markers such as IL-6, with a positive relation to serum levels and more significant

\section{Etiology of the inflammatory process}

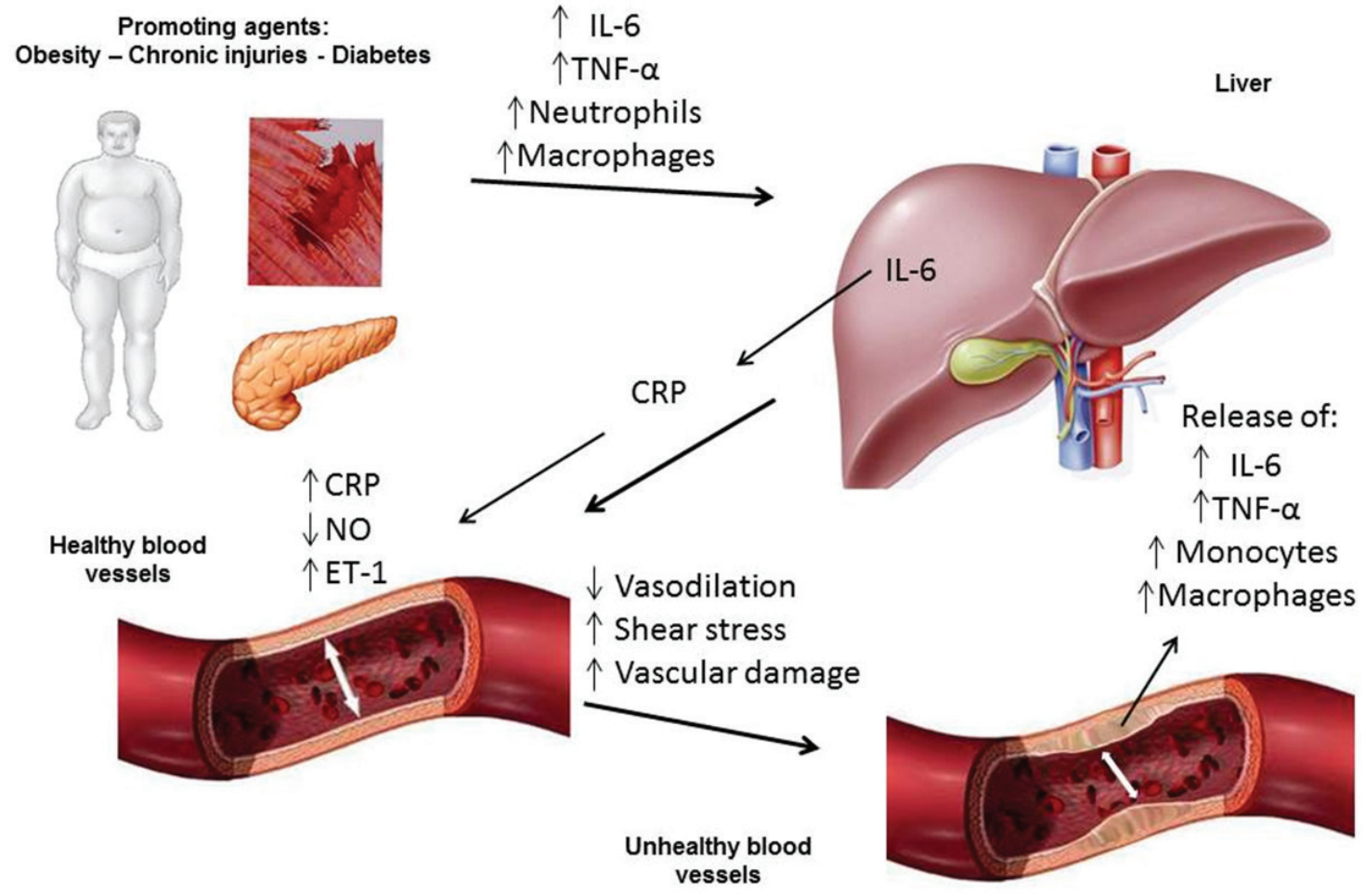

Figure 1. Etiology of the inflammatory process. Low level chronic inflammation increases the concentrations of markers and of inflammatory cells, leading to increased production of C-reactive protein (CRP) by the liver, in response to interleukin- 6 (IL-6), which provokes a reduction in vasodilation and an increase in vascular damage. TNF- $\alpha-$ Tumor necrosis factor alpha; IL-6 - Interleukin-6; CRP - C-reactive protein; NO - nitric oxide; ET-1 - Endothelin-1. 
increases during hyperglycemia pulses, which are common among diabetics. ${ }^{33}$

It has been proposed that the relationship between advancing age and increasing serum IL-6 levels is responsible for some of the phenotypical changes seen in aging, in particular those that are related to chronic inflammatory disease, such as reduction in lean body mass, osteopenia, anemia, reduced albumin levels and elevated concentrations of inflammatory proteins such as IL-6. Additionally, increased age in association with IL-6 has been linked to lymphoproliferative diseases, multiple myelomas, osteoporosis and Alzheimer's disease. ${ }^{34}$

Interleukin 6 plays an important role in the process of rupture or erosion of atherosclerotic plaques, and its serum levels are elevated during these events. ${ }^{33}$ This increase may be related to the increase in CRP, since IL-6 promotes hepatic synthesis of this protein; although CRP has its own atherogenic effects, mediated part by IL-6 synthesis. ${ }^{35}$ Among healthy men, elevated IL-6 levels are associated with increased risk of future myocardial ischemia. ${ }^{35}$

The involvement of inflammatory markers in the development of atherosclerotic disease has already been well-established, making them useful for predicting cardiovascular risk among middle-aged people. Some studies have shown that CRP levels are an important cardiovascular risk factor among healthy individuals. ${ }^{36}$ There are, however, some authors who contest this link..$^{37,38}$ One study that only enrolled elderly people showed that CRP and fibrinogen may not be as useful as IL- 6 and TNF- $\alpha$. Among patients over the age of 65 , IL- 6 and TNF- $\alpha$ have proved to be good predictors of cardiovascular events. ${ }^{39}$ Ramos et al. (2009) investigated the time taken for atherosclerotic plaques to stabilize in acute coronary syndromes (SCA), using inflammatory markers such as CRP, TNF- $\alpha$, fibrinogen and IL6 , concluding that only IL-6 was significantly and independently correlated with the occurrence of future cardiovascular events. ${ }^{11}$ This same study also found that fibrinogen and TNF- $\alpha$ levels were not useful indicators for assessing plaque stabilization, since they were not significantly higher than in a control group.

Judging from the many different studies of IL-6 that were assessed for this review, there is not yet any consensus on assay methods or reference values. Routine adoption of tests for cytokines, including IL-6 and other markers of inflammatory activity such as CRP, is still dependent on further observations; it should be noted that the methodologies involved are expensive.

\section{C-REACTIVE PROTEIN (CRP) AND ENDOTHELIUM}

C-reactive protein is an inflammatory marker synthesized in hepatocytes in response to primary stimulation from IL-6. Under acute inflammatory conditions, CRP levels increase during the first 6 to 8 hours and may reach levels as high as $300 \mathrm{mg} / \mathrm{dl}$ within 48 hours. ${ }^{40}$ Its role in inflammation and the fact that it leaves traces normally detected in blood means that it can be employed as a predictor of risk of cardiovascular events, through its interaction with classic risk factors such as creatine kinase $(\mathrm{CK})$ and lactate dehydrogenase (LDH) ${ }^{12}$

$\mathrm{C}$-reactive protein can be considered a biomarker of the process of endothelial dysfunction ${ }^{33}$ and, at supraphysiological concentrations, as a predictor of vascular disease. It also plays an important role in down regulation of eNOS and in transcription of endothelial cells, which causes destabilization of eNOS-RNA. This process results in reduced production of NO. ${ }^{10}$

It is the relationship between CRP and eNOS deficiency that appears to be the important point in atherogenesis and this influence can be easily observed by analysis of cultured endothelial cells from the human aorta. After pre-incubation with CRP, expression of eNOS (normally abundant in this type of culture) is significantly reduced, leading to a significant increase in adhesion molecule levels (Figure 2). ${ }^{41} \mathrm{C}$-reactive protein can also act to stimulate endothelin ET-1, which is a regulator of adhesion molecules, thereby facilitating entrance of LDL into macrophages via MCP-1. It also acts to regulate nuclear factor-kappa beta, which is responsible for facilitating a number of pro-atherosclerotic genes, acting at the level of vasodilatory prostacyclins, reducing production. ${ }^{35,42}$

$\mathrm{C}$-reactive protein induces instability of the fibrous layer of the atheroma, by stimulating the matrix metalloproteinase-1 (MMP-1), liberated when collagen and proteins break down, and also reduces fibrinolysis and promotes synthesis of plasminogen activator inhibitor (PAI-1). ${ }^{43}$ Both adhesion and platelet activation increase when CRP is released by monocyte tissue factor, reducing $\mathrm{NO}$ and prostacyclin concentrations.

C-reactive protein can act as a mediator of atherosclerotic plaque formation, through its role in inhibition of proteins that mediate the complement. The complement system is a complex enzymatic cascade of regulatory proteins that normally perform functions in defense mechanisms through the pathways of opsonization, chemoattraction of 
leukocytes and cell lysis and activation, in addition to its role in promotion of the inflammatory phenotype. ${ }^{11}$

Some studies have show that when CRP levels are elevated, deregulation of the equilibrium between coagulation and fibrinolysis can occur. C-reactive protein reduces the concentration of tissue plasminogen activator (tPA), responsible for lysing clots at the vessel wall, and increases PAI1 concentrations, which inhibits the fibrinolysis process (Figure 3). This facilitates formation of thrombi on the endothelial wall, which also increases the risk of cardiovascular events. ${ }^{43,44}$

C-reactive protein is therefore more than merely an inflammatory marker of atherosclerosis and coronary events, it also mediates the disease through its contribution to formation of lesions and rupture of plaques and to coronary thrombosis mechanisms.

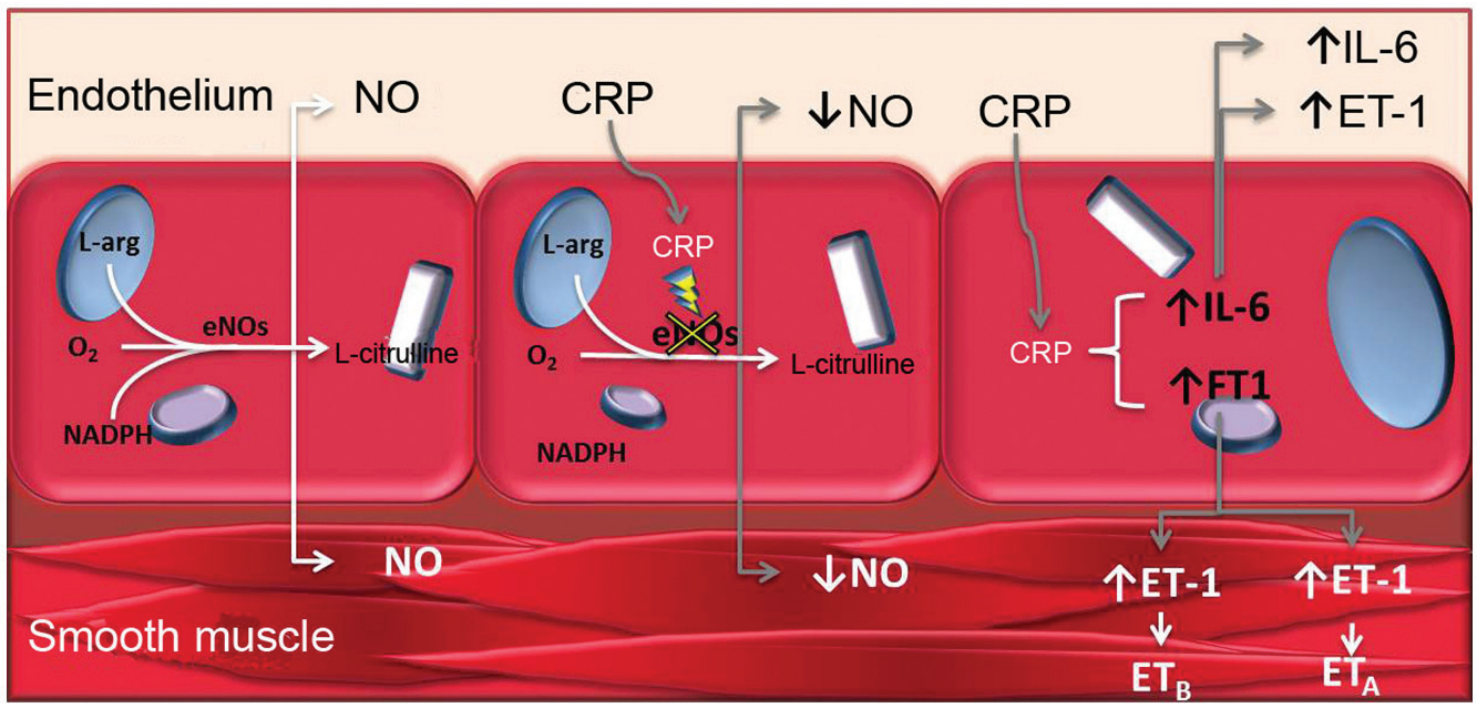

Figure 2. Mechanism reducing nitric oxide (NO) production through inhibition of the nitric oxide synthase (eNOS) enzyme by C-reactive protein (CRP). NO - nitric oxide; CRP - C-reactive protein; ET - Endothelin; IL-6 - Interleukin-6; 0 Oxygen; $\mathrm{NADPH}$ - nicotinamide adenine dinucleotide phosphate.

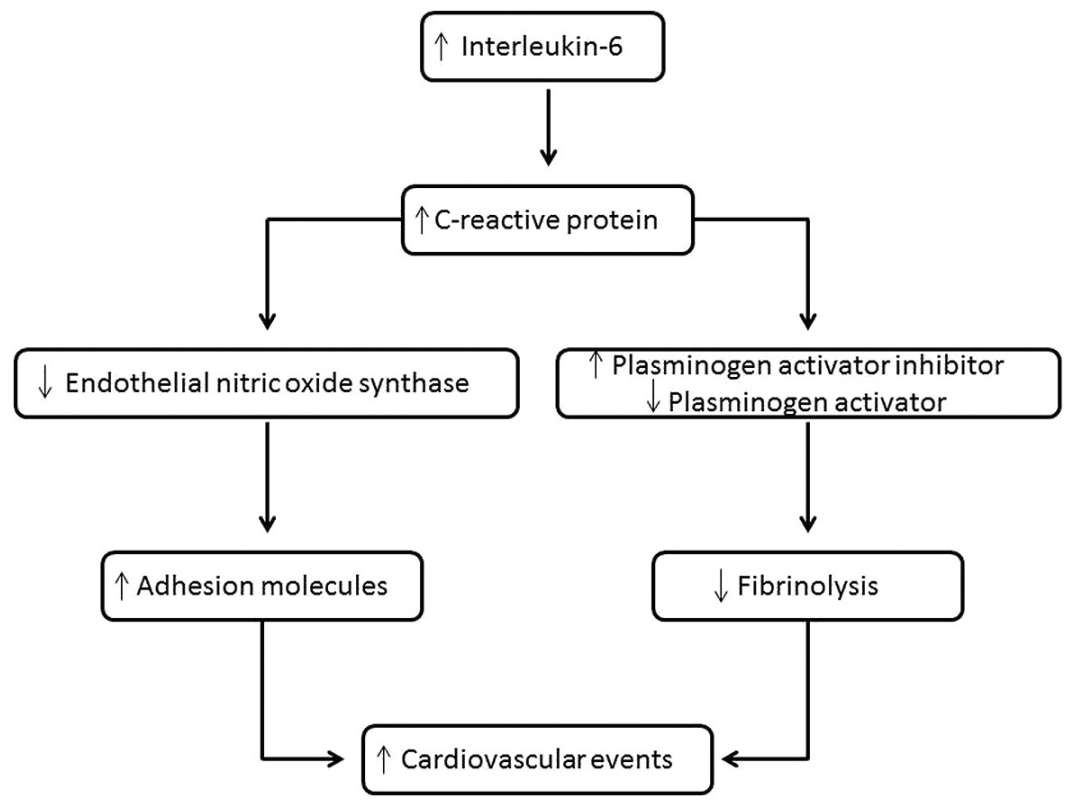

Figure 3. Sequence of events from increase of interleukin-6 levels to occurrence of cardiovascular events. 


\section{CONCLUSIONS}

On the basis of the articles reviewed, we conclude that increased levels of inflammatory markers are related to endothelial dysfunction. Increases in some of these markers, such as Il-6, which stimulates increases in CRP, are related to reductions in NO concentrations caused by reduced eNOS activity. This reduction can cause a reduction in endotheliumdependent vasodilation, which can increase the risk of endothelial dysfunction and cardiovascular diseases.

\section{REFERENCES}

1. Go AS, Mozaffarian D, Roger VL, Benjamin EJ, Berry JD, Borden WB, et al. Heart disease and stroke statistics--2013 update: a report from the American Heart Association. Circulation. 2013;127:e6-e245. PMid:23239837. http://dx.doi.org/10.1161/ CIR.0b013e31828124ad

2. Schmidt MI, Duncan BB, Azevedo e Silva G, Menezes AM, Monteiro CA, Barreto SM, et al. Chronic non-communicable diseases in Brazil: burden and current challenges. Lancet. 2011;377:1949-1961. http://dx.doi.org/10.1016/S0140-6736(11)60135-9

3. Barbato JE, Tzeng E. Nitric oxide and arterial disease. J Vasc Surg. 2004;40:187-193. PMid:15218485. http://dx.doi.org/10.1016/j. jvs.2004.03.043

4. Leung FP, Yung LM, Laher I, Yao X, Chen ZY, Huang Y. Exercise, vascular wall and cardiovascular diseases: an update (Part 1). Sports Med. 2008;38:1009-1024. PMid:19026018. http://dx.doi. org/10.2165/00007256-200838120-00005

5. Machado BH, Bonagamba LG. Microinjection of S-nitrosocysteine into the nucleus tractus solitarii of conscious rats decreases arterial pressure but L-glutamate does not. Eur J Pharmacol. 1992;221:179182. http://dx.doi.org/10.1016/0014-2999(92)90791-2

6. Luscher TF, Seo BG, Buhler FR. Potential role of endothelin in hypertension. Controversy on endothelin in hypertension. Hypertension. 1993;21:752-757. PMid:8500855. http://dx.doi. org/10.1161/01.HYP.21.6.752

7. Reinhardt RR, Bondy CA. Differential cellular pattern of gene expression for two distinct CGMP-inhibited cyclic nucleotide phosphodiesterases in developing and mature rat brain. Neuroscience. 1996;72:567-578. http://dx.doi. org/10.1016/0306-4522(95)00520-X

8. Verma S, Devaraj S, Jialal I. Is C-reactive protein an innocent bystander or proatherogenic culprit? C-reactive protein promotes atherothrombosis. Circulation. 2006;113:2135-2150; discussion 2150. PMid:16671184

9. Szmitko PE, Wang CH, Weisel RD, De Almeida JR, Anderson TJ, Verma S. New markers of inflammation and endothelial cell activation: Part I. Circulation. 2003;108:1917-1923. PMid:14568885. http://dx.doi.org/10.1161/01.CIR.0000089190.95415.9F

10. Tonet AC, Karnikowski M, Moraes CF, et al. Association between the $-174 \mathrm{G} / \mathrm{C}$ promoter polymorphism of the interleukin -6 gene and cardiovascular disease risk factors in Brazilian older women. Braz J Med Biol Res. 2008;41:47-53. PMid:17994165. http://dx.doi. org/10.1590/S0100-879X2006005000190

11. Ramos AM, Pellanda LC, Gus I, Portal VL. Inflammatory markers of cardiovascular disease in the elderly. Arq Bras Cardiol. 2009;92:221-228, 227-234.
12. Libby P, Ridker PM, Maseri A. Inflammation and atherosclerosis. Circulation. 2002;105:1135-1143. PMid:11877368. http://dx.doi. org/10.1161/hc0902.104353

13. Westfelt UN, Benthin G, Lundin S, Stenqvist O, Wennmalm A. Conversion of inhaled nitric oxide to nitrate in man. Br J Pharmacol. 1995;114:1621-1624. PMid:7599931 PMCid:PMC1510380. http:// dx.doi.org/10.1111/j.1476-5381.1995.tb14948.x

14. Palmer RM, Ferrige AG, Moncada S. Nitric oxide release accounts for the biological activity of endothelium-derived relaxing factor. Nature. 1987;327:524-526. PMid:3495737. http://dx.doi. org/10.1038/327524a0

15. Hein TW, Singh U, Vasquez-Vivar J, Devaraj S, Kuo L, Jialal I. Human C-reactive protein induces endothelial dysfunction and uncoupling of eNOS in vivo. Atherosclerosis. 2009;206:61-68. PMid:19268941 PMCid:PMC2735606. http://dx.doi.org/10.1016/j. atherosclerosis.2009.02.002

16. Thijssen DH, Black MA, Pyke KE, et al. Assessment of flowmediated dilation in humans: a methodological and physiological guideline. Am J Physiol Heart Circ Physiol. 2011;300:H2-12. PMid:20952670 PMCid:PMC3023245. http://dx.doi.org/10.1152/ ajpheart.00471.2010

17. Nathan C, Xie QW. Regulation of biosynthesis of nitric oxide. J Biol Chem. 1994;269:13725-13728. PMid:7514592.

18. Wilcox JN, Subramanian RR, Sundell CL, et al. Expression of multiple isoforms of nitric oxide synthase in normal and atherosclerotic vessels. Arterioscler Thromb Vasc Biol. 1997;17:2479-2488. PMid:9409218. http://dx.doi.org/10.1161/01. ATV.17.11.2479

19. Vasquez-Vivar J, Kalyanaraman B, Martasek P, et al. Superoxide generation by endothelial nitric oxide synthase: the influence of cofactors. Proc Natl Acad Sci U S A. 1998;95:9220-9225. PMid:9689061 PMCid:PMC21319. http://dx.doi.org/10.1073/ pnas.95.16.9220

20. Kuzkaya N, Weissmann N, Harrison DG, Dikalov S. Interactions of peroxynitrite, tetrahydrobiopterin, ascorbic acid, and thiols: implications for uncoupling endothelial nitric-oxide synthase. Biol Chem. 2003;278:22546-22554. PMid:12692136. http://dx.doi org/10.1074/jbc.M302227200

21. Verma $\mathrm{S}$, Wang $\mathrm{CH}$, Li SH, et al. A self-fulfilling prophecy: $\mathrm{C}$-reactive protein attenuates nitric oxide production and inhibits angiogenesis. Circulation. 2002;106:913-919. PMid:12186793. http://dx.doi.org/10.1161/01.CIR.0000029802.88087.5E

22. Schwedler SB, Kuhlencordt PJ, Ponnuswamy PP, et al. Native C-reactive protein induces endothelial dysfunction in ApoE1- mice: implications for iNOS and reactive oxygen species. Atherosclerosis. 2007;195:e76-84. PMid:17669410. http://dx.doi. org/10.1016/j.atherosclerosis.2007.06.013

23. Fichtlscherer S, Rosenberger $\mathrm{G}$, Walter DH, Breuer S, Dimmeler $S$, Zeiher AM. Elevated C-reactive protein levels and impaired endothelial vasoreactivity in patients with coronary artery disease. Circulation. 2000;102:1000-1006. PMid:10961964. http://dx.doi. org/10.1161/01.CIR.102.9.1000

24. Sinisalo J, Paronen J, Mattila KJ, et al. Relation of inflammation to vascular function in patients with coronary heart disease. Atherosclerosis. 2000;149:403-411. http://dx.doi.org/10.1016/ S0021-9150(99)00333-0

25. Tan KC, Chow WS, Tam SC, Ai VH, Lam CH, Lam KS. Atorvastatin lowers $\mathrm{C}$-reactive protein and improves endothelium-dependent vasodilation in type 2 diabetes mellitus. J Clin Endocrinol Metab. 2002;87:563-568. PMid:11836286. http://dx.doi.org/10.1210/ jcem.87.2.8249 
26. Brevetti G, Silvestro A, Schiano V, Chiariello M. Endothelial dysfunction and cardiovascular risk prediction in peripheral arterial disease: additive value of flow-mediated dilation to ankle-brachial pressure index. Circulation. 2003;108:2093-2098. PMid:14530195. http://dx.doi.org/10.1161/01.CIR.0000095273.92468.D9

27. De Haro Miralles J, Martinez-Aguilar E, Florez A, Varela C, Bleda $S$, Acin F. Nitric oxide: link between endothelial dysfunction and inflammation in patients with peripheral arterial disease of the lower limbs. Interact Cardiovasc Thorac Surg. 2009;9:107-112. PMid:19376804. http://dx.doi.org/10.1510/icvts.2008.196428

28. Rizzo M, Corrado E, Coppola G, Muratori I, Novo G, Novo S. Markers of inflammation are strong predictors of subclinical and clinical atherosclerosis in women with hypertension. Coron Artery Dis. 2009;20:15-20. PMid:19060627. http://dx.doi.org/10.1097/ MCA.0b013e3283109065

29. Antoniades C, Demosthenous M, Tousoulis D, et al. Role of asymmetrical dimethylarginine in inflammation-induced endothelial dysfunction in human atherosclerosis. Hypertension. 2011;58:93-98. PMid:21518967. http://dx.doi.org/10.1161/ HYPERTENSIONAHA.110.168245

30. Leinonen E, Hurt-Camejo E, Wiklund O, Hultén LM, Hiukka A, Taskinen MR. Insulin resistance and adiposity correlate with acute-phase reaction and soluble cell adhesion molecules in type 2 diabetes. Atherosclerosis. 2003;166(2):387-94. PMid:12535753. http://dx.doi.org/10.1016/S0021-9150(02)00371-4

31. Gleeson M, Bishop NC, Stensel DJ, Lindley MR, Mastana SS, Nimmo MA. The anti-inflammatory effects of exercise: mechanisms and implications for the prevention and treatment of disease. Nat Rev Immunol. 2011;11:607-615. PMid:21818123. http://dx.doi.org/10.1038/nri3041

32. Brevetti G, De Caterina $M$, Martone VD, et al. Exercise increases soluble adhesion molecules ICAM-1 and VCAM- 1 in patients with intermittent claudication. Clin Hemorheol Microcirc. 2001;24:193-199. PMid:11455059.

33. Souza JR, Oliveira RT, Blotta MH, Coelho OR. Níveis séricos de interleucina-6 (IL-6), interleucina-18 (IL-18) e proteína- $C$ reativa (PCR) na síndrome coronariana aguda sem supradesnivelamento doST em pacientes com diabete tipo 2. Arq Bras Cardiol. 2008;90:9499. http://dx.doi.org/10.1590/S0066-782X2008000200004

34. Ershler WB, Keller ET. Age-associated increased interleukin-6 gene expression, late-life diseases, and frailty. Annu Rev Med. 2000;51:245-270. PMid:10774463. http://dx.doi.org/10.1146/ annurev.med.51.1.245

35. Lindmark E, Diderholm E, Wallentin L, Siegbahn A. Relationship between interleukin 6 and mortality in patients with unstable coronary artery disease: effects of an early invasive or noninvasive strategy. JAMA. 2001;286:2107-2113. PMid:11694151. http://dx.doi.org/10.1001/jama.286.17.2107

36. Athyros VG, Tziomalos K, Karagiannis A, Mikhailidis DP. The JUPITER trial results boost the evidence for the use of hsCRP as a treatment target and as part of the assessment of vascular risk: time for new guidelines? Hellenic J Cardiol. 2009;50:89-91. PMid:19329409.

37. Gomez M, Valle V, Aros F, et al. Oxidized LDL, lipoprotein (a) and other emergent risk factors in acute myocardial infarction (FORTIAM study). Rev Esp Cardiol. 2009;62:373-382. PMid:19401122.

38. Huelmos A, Jimenez ], Guijarro C, et al. [Underrecognized peripheral arterial disease in patients with acute coronary syndrome: prevalence of traditional and emergent cardiovascular risk factors]. Rev Esp Cardiol. 2005;58:1403-1410. http://dx.doi. org/10.1016/S0300-8932(05)74070-7
39. Ross R. The pathogenesis of atherosclerosis: a perspective for the 1990s. Nature. 1993;362:801-809. PMid:8479518. http://dx.doi. org/10.1038/362801a0

40. Steffel J, Luscher TF. Predicting the development of atherosclerosis. Circulation. 2009;119:919-921. PMid:19237671. http://dx.doi. org/10.1161/CIRCULATIONAHA.108.846725

41. Fantuzzi G, Reed DA, Dinarello CA. IL-12-induced IFN-gamma is dependent on caspase-1 processing of the IL-18 precursor. J Clin Invest. 1999;104:761-767. PMid:10491411 PMCid:PMC408443. http://dx.doi.org/10.1172/JCI7501

42. Ridker PM, Rifai N, Stampfer MJ, Hennekens CH. Plasma concentration of interleukin- 6 and the risk of future myocardial infarction among apparently healthy men. Circulation. 2000;101:1767-1772. PMid:10769275. http://dx.doi. org/10.1161/01.CIR.101.15.1767

43. Devaraj S, Xu DY, Jialal I. C-reactive protein increases plasminogen activator inhibitor- 1 expression and activity in human aortic endothelial cells: implications for the metabolic syndrome and atherothrombosis. Circulation. 2003;107:398-404. PMid:12551862. http://dx.doi.org/10.1161/01.CIR.0000052617.91920.FD

44. Singh U, Devaraj S, Jialal I. C-reactive protein decreases tissue plasminogen activator activity in human aortic endothelial cells: evidence that C-reactive protein is a procoagulant. Arterioscler Thromb Vasc Biol. 2005;25:2216-2221. PMid:16123325. http:// dx.doi.org/10.1161/01.ATV.0000183718.62409.ea

Correspondence Bruno Teixeira

Universidade Federal do Rio Grande do Sul - Departamento de Educação Física

Rua Felizardo, 750 - Jardim Botânico CEP 90690-200 - Porto Alegre (RS), Brazi

Tel.: +55 (51) 3308-5862

E-mail: brunoct100@hotmail.com

Author information BCT, ALL, RCOM e CSC são mestres em Ciências do Movimento Humano pela Universidade Federal do Rio Grande do Sul (UFRGS) e doutorandos em Ciências do Movimento Humano pela UFRGS TRR é mestrando em Reabilitação e Inclusão pelo Centro Universitário Metodista (IPA).

JLR é doutor em Ciências do Movimento Humano pela Universidade Federal do Rio Grande do Sul (UFRGS) e coordenador do Programa de Pós-Graduação em Reabilitação e Inclusão do Centro Universitário Metodista (IPA)

ARO é doutor em Fisiologia pela Universidade Federal do Rio Grande do Sul (UFRGS).

Author contributions

Conception and design: BCT, JLR, ALL Analysis and interpretation: TRR, CSC, RCOM, BCT, JLR Data collection: ALL, RCOM, BCT Writing the article: BCT, TRR, CSC, ALL, RCOM

Critical revision of the article: $A R O, B C T$, JLR Final approval of the article*: TRR, CSC, RCOM, BCT, JLR, ALL, ARO

Statistical analysis: N/A Overall responsibility: ARO

*All authors have read and approved of the final version of the article submitted to I Vasc Bras. 